\title{
Changes in the spectrum and rates of extracellular enzyme activities in seawater following aggregate formation
}

\author{
K. Ziervogel ${ }^{1}$, A. D. Steen ${ }^{1, *}$, and C. Arnosti ${ }^{1}$ \\ ${ }^{1}$ Department of Marine Sciences, University of North Carolina at Chapel Hill, Chapman Hall, CB\#3300, Chapel Hill, NC \\ 27599-3300, USA \\ * now at: Center for Geomicrobiology, University of Århus, Ny Munkgade 1540, 0800 Århus C, Denmark
}

Received: 16 November 2009 - Published in Biogeosciences Discuss.: 1 December 2009

Revised: 24 February 2010 - Accepted: 8 March 2010 - Published: 15 March 2010

\begin{abstract}
Marine snow aggregates are heavily colonized by heterotrophic microorganisms that express high levels of hydrolytic activities, making aggregates hotspots for carbon remineralization in the ocean. To assess how aggregate formation influences the ability of seawater microbial communities to access organic carbon, we compared hydrolysis rates of six polysaccharides in coastal seawater after aggregates had been formed (via incubation on a roller table) with hydrolysis rates in seawater from the same site that had not incubated on a roller table (referred to as whole seawater). Hydrolysis rates in the aggregates themselves were up to three orders of magnitude higher on a volume basis than in whole seawater. The enhancement of enzyme activity in aggregates relative to whole seawater differed by substrate, suggesting that the enhancement was under cellular control, rather than due to factors such as lysis or grazing. A comparison of hydrolysis rates in whole seawater with those in aggregatefree seawater, i.e. the fraction of water from the roller bottles that did not contain aggregates, demonstrated a nuanced microbial response to aggregate formation. Activities of laminarinase and xylanase enzymes in aggregate-free seawater were higher than in whole seawater, while activities of chondroitin, fucoidan, and arabinogalactan hydrolyzing enzymes were lower than in whole seawater. These data suggest that aggregate formation enhanced production of laminarinase and xylanase enzymes, and the enhancement also affected the surrounding seawater. Decreased activities of chondroitin, fucoidan, and arabinoglactan-hydrolyzing enzymes in aggregate-free seawaters relative to whole seawater are likely due to shifts in enzyme production by the aggregate-
\end{abstract}

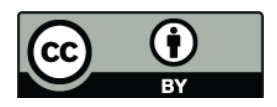

Correspondence to: K. Ziervogel (ziervoge@email.unc.edu) associated community, coupled with the effects of enzyme degradation. Enhanced activities of laminarin- and xylanhydrolyzing enzymes in aggregate-free seawater were due at least in part to cell-free enzymes. Measurements of enzyme lifetime using commercial enzymes suggest that hydrolytic cell-free enzymes may be active over timescales of days to weeks. Considering water residence times of up to 10 days in the investigation area (Apalachicola Bay), enzymes released from aggregates may be active over timescales long enough to affect carbon cycling in the Bay as well as in the adjacent Gulf of Mexico. Aggregate formation may thus be an important mechanism shaping the spectrum of enzymes active in the ocean, stimulating production of cell-free enzymes and leading to spatial and temporal decoupling of enzyme activity from the microorganisms that produced them.

\section{Introduction}

Marine snow aggregates play a central role in transformation processes of organic and inorganic matter in marine environments. Due to their high sinking velocities, aggregates accelerate the vertical transport of particulate matter from the ocean's surface towards the sediment. In the open ocean, marine snow often forms at the decline of phytoplankton blooms as the stickiness of exudates increases the coagulation efficiency of particulate matter (Simon et al., 2002). Aggregate formation in shallow coastal waters may also be driven by hydrodynamic processes, since aggregates frequently form at the transition of fresh and marine waters due to salinity changes and flow dynamics (Gibbs et al., 1983; Wolanski and Gibbs, 1995). Wind-driven water turbulence may also induce aggregate formation, a process that has been observed

Published by Copernicus Publications on behalf of the European Geosciences Union. 
in lakes (Grossart and Simon, 1998). Aggregates may also form layers of easily resuspendable sediments affecting inorganic and organic matter transport in shallow coastal waters as well as the adjacent ocean (Cook et al., 2007; Ziervogel and Arnosti, 2009).

Bacteria densely colonize marine snow (Alldredge et al., 1986) and aggregate-associated microbial processes such as enzyme activities have often been found to be elevated relative to the surrounding water (Smith et al., 1992; Ploug et al., 1999; Grossart et al., 2003, 2007), making marine snow hotspots for carbon remineralization (Azam and Long, 2001). For instance, in the Baltic Sea, Grossart et al. (2003) found 100 to 360 times higher cell-specific protease and $\beta$ glucosidase activities, respectively, in aggregates compared to water surrounding the aggregates. As aggregates often harbor diverse communities of microorganisms that differ from their free living counterparts (DeLong et al., 1993; Bidle and Fletcher, 1995; Tuomainen et al., 2006), differences in microbial community structure may explain variations in the level of cell-specific activity.

Physical attachment of microorganisms onto aggregates may also trigger or enhance the production of specific enzymes (Baty et al., 2000). A laboratory study with pure cultures of bacteria isolated from marine snow showed a 20 -fold increase in enzyme activity within $2 \mathrm{~h}$ of particle attachment (Grossart et al., 2007). Elevated microbial activities and extracellular enzyme production on aggregates may result from bacterial quorum sensing (Miller and Bassler, 2001) that has been demonstrated to occur in marine snow isolates (Gram et al., 2002). The threshold for bacterial abundances necessary to induce quorum sensing in the ocean may in fact only be reached on marine snow particles (Hmelo and Van Mooy, 2009). Alternatively, enhanced production and release of extracellular enzymes from aggregate-associated microorganisms may be due to eukaryotic grazing (Kiørboe et al., 2003) or viral lysis (Riemann and Grossart, 2008).

Despite the important role that aggregate-associated microbes play in the pelagic carbon cycle, the substrate specificities and activities of extracellular enzymes produced by aggregate-associated microbial communities are still largely unexplored. Previous investigations assessing marine-snow associated enzyme activities have relied primarily on small substrate proxies (Hoppe, 1983). Although such measurements can be made rapidly, they cannot distinguish between the activities of periplasmic and extracellular enzymes (Martinez and Azam, 1993), nor do they measure the activites of endo-acting extracellular enzymes that are responsible for midchain-cleavage of high molecular weight biomacromolecules (polysaccharides, proteins, and lipids) to sizes suitable for uptake (typically $<600 \mathrm{Da}$; Weiss et al., 1991). Moreover, the structural specificity within broad classes of enzymes (such as polysaccharide hydrolases) cannot be determined with substrate proxies.

In this study, we used six structurally distinct polysaccharides to investigate activities of endo-acting extracellular enzymes in seawater with and without aggregates that were formed by incubating seawater on a roller table (Shanks and Edmondson, 1989). Using these substrates, we have demonstrated differences in the substrate spectrum of polysaccharide hydrolases active in seawater (Arnosti et al., 2005) as well as in aggregates and aggregate-free seawaters with substantial particle/cell-free extracellular enzyme activities (Ziervogel and Arnosti, 2008). On the basis of those data, we hypothesized that the formation of aggregates triggers enzyme production by aggregate-associated microorganisms and that some of these enzymes escape the aggregates, adding to total hydrolytic activities in the water column. We investigated this hypothesis directly in the current study. In order to estimate the spatial and temporal scales over which enzymes released from (or not incorporated into) aggregates may affect total hydrolytic activity in seawater and thus impact carbon cycling processes, we also measured the effective lifetimes of two commercially-available enzymes in artificial seawater (ASW).

\section{Material and methods}

\subsection{Study site and water sampling}

Surface water (water depth: $1.5 \mathrm{~m}$ ) was collected using a ten liter acid- and seawater-rinsed canister in Apalachicola Bay near the shore of St. George Island $\left(29^{\circ} 39989^{\prime} \mathrm{N}\right.$, $84^{\circ} 52139^{\prime} \mathrm{W}$; Bay site in Arnosti et al., 2009; Ziervogel and Arnosti, 2008), north-eastern Gulf of Mexico in May 2006 and September 2008 (hereafter referred to as spring 2006 and fall 2008). Apalachicola Bay is approximately $40 \mathrm{~km}$ long and $7 \mathrm{~km}$ wide with an average water depth of $3 \mathrm{~m}$. It is connected to the Gulf of Mexico through five openings, and has a relatively short water residence time of 3 to 10 days (Huang and Spaulding, 2002). Its main freshwater tributary is the Apalachicola River, with strong daily discharge that is generally higher in spring compared to summer and autumn. Freshwater discharge affects nutrient dynamics as well as primary productivity in the Bay (Mortazavi et al., 2000, 2001). During sampling in spring 2006 and fall 2008, surface water salinity was 20 and $26 \mathrm{PSU}$ and water temperature was 21 and $26^{\circ} \mathrm{C}$, respectively.

\subsection{Aggregate formation and hydrolysis experiments}

Marine snow aggregates were formed with surface seawater in the lab using rotating tanks placed on a roller table (Shanks and Edmondson, 1989; Ziervogel and Arnosti, 2008). Aggregates formed within rotating tanks have been found to resemble natural marine snow in terms of size and composition and are thus suitable to study microbial processes on marine snow (Unanue et al., 1998).

Water was filled into 2-1 glass bottles and bottles were rotated on a roller table at $6 \mathrm{rpm}$. To sample aggregates, bottles were placed upright on a bench top to allow aggregates to 
settle to the bottom. Newly formed aggregates were carefully withdrawn using a 5-ml glass pipette and transferred into separate glass tubes for hydrolysis experiments. The aim was to fill the tubes with equal amounts of aggregates. The transfer may have affected aggregates shape and size due to disaggregation and/or compaction. However, particle association of bacteria cells likely remained unaffected since epifluorescence microscopy of an aggregate sample treated as described above revealed that bacteria cells were clumped together and associated with particles (data not shown).

Enzymatic hydrolysis of six structurally distinct, fluorescently-labeled polysaccharides (arabinoglactan, chondroitin sulfate, fucoidan, laminarin, pullulan, xylan; all from Fluka or Sigma; fluorescently labeled as described in Arnosti, 1995, 2003) was measured in aggregates, in water surrounding aggregates (hereafter referred to as aggregate-free seawater), and in unfiltered seawater not placed on the roller table (hereafter referred to as whole seawater). Aggregate-free seawater and aggregates, the latter suspended in $15 \mathrm{ml} 0.1-\mu \mathrm{m}$ filtered and autoclaved ASW (Sigma sea salts; $35 \mathrm{~g} \mathrm{~L}^{-1}, \mathrm{pH}$ adjusted to 8.2), were incubated in duplicate (spring 2006) and triplicate (fall 2008) scintillation vials. Hydrolysis rates in whole seawater were measured in triplicate incubations.

Sample analysis using a gel permeation chromatography system was performed as described in Ziervogel and Arnosti (2008). The total time course of hydrolysis experiments varied between 7 (aggregates and aggregate-free seawater) and 15 days (whole seawater) in spring 2006 and 20 days for all experiments in fall 2008. The maximum hydrolysis rates reported here (Table 1; Fig. 1) were usually measured at time points within the first week of incubations. In spring 2006, however, the maximum rates were measured at 10 days for arabinoglacatan and pullulan in whole seawater; in fall 2008 maximum rates were measured at 20 days for arabinogalactan in aggregate-free and whole seawater as well as for fucoidan in aggregates.

For aggregates, volume-normalized hydrolysis rates were calculated using the numerical relationship of aggregate dry weight and volume of natural marine snow given by Alldredge and Gotschalk (1988). Aggregate dry weight was determined following incubations for hydrolysis measurements after centrifuging the samples, discarding the supernatant, and replacing it with $0.2-\mu \mathrm{m}$ filtered Milli-Q water in order to remove salt; this procedure was repeated 3 times. Thereafter, samples were dried at $60^{\circ} \mathrm{C}$ until constant weight was reached.

Because rates were normalized to aggregate volume, rates are reported in units of nmol $\mathrm{Lagg}^{-1} \mathrm{~h}^{-1}$. Total hydrolysis rates in roller bottles were calculated from the sum of hydrolysis rates measured in aggregates (normalized to the total volume within roller bottles; see Results) and in aggregatefree seawater (Fig. 1). Note that results from whole seawater hydrolysis experiments in spring 2006 have been reported in Arnosti et al. (2009). Changes in polysaccharide molecular weight (but not hydrolysis rates) in aggregates and aggregatefree seawaters from spring 2006 were also reported by Ziervogel and Arnosti (2008). Potential hydrolysis rates were calculated from the changes in substrate molecular weight as described in Arnosti (1995, 2003).

\subsection{Activities of commercial enzymes in ASW and measurement of enzyme half-life}

All enzyme degradation rate experiments were carried out in a temperature-controlled room at $20^{\circ} \mathrm{C}$. To measure $\alpha$ glucosidase degradation, $210 \mu \mathrm{g} \alpha$-glucosidase (Sigma, from Saccharomyces cervisiae) was added to $500 \mathrm{ml}$ sterile ASW. To measure phosphatase degradation, $30.5 \mathrm{ng}$ alkaline phosphatase (Sigma, from bovine intestinal mucosa) was added to $200 \mathrm{ml}$ sterile ASW. At each time point, duplicate $2 \mathrm{ml}$ subsamples were removed and mixed directly in methacrylate fluorescence cuvettes with 4-methylumbelliferyl- $\alpha$-Dglucopyranoside (MUF- $\alpha$-glu, Sigma, for $\alpha$-glucosidase) or 4-methylumbelliferyl-phosphate (MUF-PO 4 , BioChimica, for phosphatase). Final substrate concentrations were $100 \mu \mathrm{M}$ (MUF- $\alpha$-glu) and $40 \mu \mathrm{M}\left(\mathrm{MUF}^{-\mathrm{PO}_{4}}\right)$.

At each time point, fluorescence was measured four times in each cuvette over the course of fifteen to twenty minutes, using a Turner Biosystems TBS-380 fluorimeter set to the UV channel. The slope of the regression line of fluorescence against time was taken as enzyme activity; data were fit to an exponential form using the curvefitting toolbox in MATLAB 7.5, and half-life was calculated from the decay constant. Activities in controls, to which no enzyme was added, were negligible.

\section{Results}

The formation of macroscopic aggregates occurred within one hour of roller table incubations on both sampling dates. Total aggregate volumes in one liter roller bottle water were similar at both dates, ranging between 0.48 and $0.63 \mathrm{~cm}^{3}$ in spring 2006 and fall 2008, respectively, i.e. on average $0.05 \%$ of the total roller bottle volume. Aggregate hydrolysis rates (Table 1) were multiplied by this factor to calculate the contribution of aggregate-associated activities to total roller bottle (aggregates+aggregate-free seawater) hydrolysis rates.

\subsection{Hydrolysis rates in aggregates}

Volume-normalized hydrolysis rates in aggregates ranged from $11.6 \times 10^{2} \mathrm{nmol} \mathrm{Lagg}^{-1} \mathrm{~h}^{-1}$ for arabinogalactan in spring 2006 to $146 \times 10^{2} \mathrm{nmol} \mathrm{Lagg}^{-1} \mathrm{~h}^{-1}$ for xylan in fall 2008 (Table 1). At both sampling dates, laminarin and xylan were most rapidly hydrolyzed in aggregates. Differences in aggregate-associated hydrolysis rates between the two sampling dates were observed for four of the six substrates. In particular, xylan hydrolysis rates in fall 2008 were 


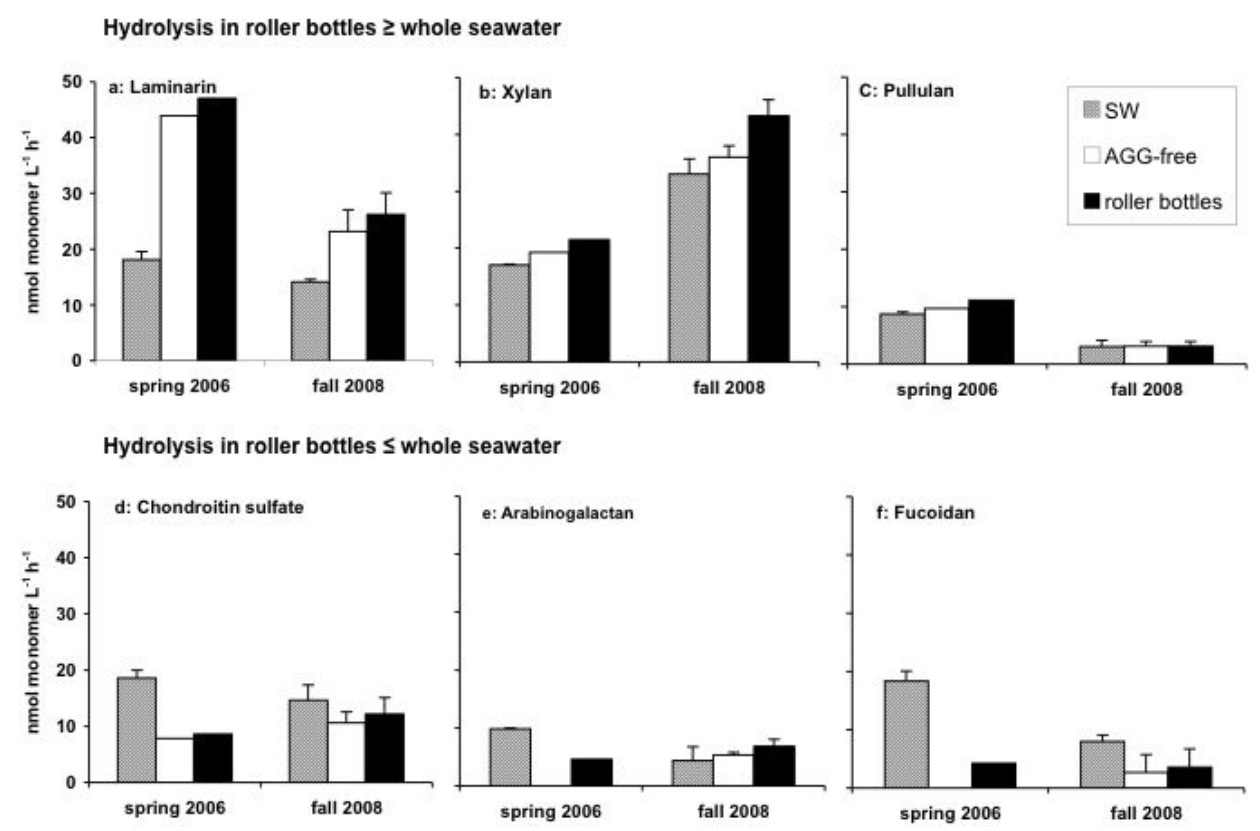

Fig. 1. Maximum hydrolysis rates in whole seawater (SW), aggregate-free seawater (AGG-free), and total roller bottle hydrolysis rates (AGG-free plus volume corrected aggregate rates; see text) in spring 2006 (SW: average of $n=3$; AGG-free and roller bottles: average of $n=2$ ) and fall 2008 (all average of $n=3 \pm$ standard deviations). SW rates in spring 2006 are from Arnosti et al. (2009).

Table 1. Maximum hydrolysis rates in aggregates (AGG) in spring 2006 (average of $n=2$ ) and fall 2008 (average of $n=3 \pm$ standard deviations), and the relationship (on a volume basis) between hydrolysis rates in AGG and whole seawater (SW) for laminarin (Lam), xylan (Xyl), pullulan (Pull), chondroitin sulfate (Chon), arabinogalactan (Ara), and fucoidan (Fu).

\begin{tabular}{lllll}
\hline \multicolumn{3}{c}{ Spring 2006 } & \multicolumn{2}{c}{ Fall 2008 } \\
\hline & $\begin{array}{l}\text { Hydrolysis rates in AGG } \\
\left(10^{2} \mathrm{nmol} \mathrm{L} \mathrm{agg}^{-1} \mathrm{~h}^{-1}\right)\end{array}$ & AGG:SW & $\begin{array}{l}\text { Hydrolysis rates in AGG } \\
\left(10^{2} \mathrm{nmol} \mathrm{L} \mathrm{agg}^{-1} \mathrm{~h}^{-1}\right)\end{array}$ & AGG:SW \\
\hline Lam & 64.2 & 360 & $60.6 \pm 0.9$ & 430 \\
Xyl & 45 & 260 & $146 \pm 35.4$ & 440 \\
Pull & 29.1 & 330 & 0 & - \\
Chon & 13 & 70 & $31 \pm 27.9$ & 210 \\
Ara & 11.6 & 120 & $30 \pm 17.5$ & 690 \\
Fu & 13.1 & 70 & $18 \pm 1.8$ & 230 \\
\hline
\end{tabular}

three times higher compared to spring 2006. Pullulan hydrolysis rates were not measurable in aggregates in fall 2008 and were $29.1 \times 10^{2} \mathrm{nmol} \mathrm{Lagg}^{-1} \mathrm{~h}^{-1}$ in spring 2006. For arabinogalactan and chondroitin sulfate, hydrolysis rates in fall 2008 were two and three times higher, respectively, than in spring 2006. In contrast, laminarin and fucoidan hydrolysis rates varied only slightly between sampling dates.

Compared to aggregate-free seawater and whole seawater, aggregate associated rates on a volume basis were 70to 700-fold higher (Fig. 1; Table 1). However corrected for their volume, aggregate associated activities only comprise 3.5 (i.e. $70 \times 0.05 \%$ ) to $35 \%$ (i.e. $700 \times 0.05 \%$ ) of aggregatefree and whole seawater hydrolysis rates.

\subsection{Hydrolysis rates in aggregate-free seawater and whole seawater}

Hydrolysis rates ranged between $2.6 \mathrm{nmol}$ monomer $\mathrm{L}^{-1} \mathrm{~h}^{-1}$ for pullulan (in aggregate-free seawater in fall 2008) and $44 \mathrm{nmol}$ monomer $\mathrm{L}^{-1} \mathrm{~h}^{-1}$ for laminarin (in aggregate-free seawater in spring 2006; Fig. 1). In fall 2008, hydrolysis rates of all substrates except xylan were lower than in spring 2006 (Fig. 1). Three of the six substrates (laminarin, xylan, and pullulan) showed higher average hydrolysis rates in aggregate-free seawater than in whole seawater (Fig. 1a-c). For laminarin, hydrolysis in aggregatefree seawater was $44 \mathrm{nmol} \mathrm{monomer} \mathrm{L}^{-1} \mathrm{~h}^{-1}$ in spring 2006 
and $23 \mathrm{nmol}$ monomer $\mathrm{L}^{-1} \mathrm{~h}^{-1}$ in fall 2008, and thus 2.4 and 1.6 times higher than whole seawater (Fig. 1a; differences were statistically significant in fall 2008; t-test, $p<0.05, n=3)$. For xylan, hydrolysis rates in aggregatefree seawater (19 and $36 \mathrm{nmol}$ monomer $\mathrm{L}^{-1} \mathrm{~h}^{-1}$ ) were also higher at both times compared to whole seawater (17 and 33 nmol monomer $\mathrm{L}^{-1} \mathrm{~h}^{-1}$; Fig. 1b). Pullulan hydrolysis was 9.7 and $8.7 \mathrm{nmol}$ monomer $\mathrm{L}^{-1} \mathrm{~h}^{-1}$ in spring 2006 and 3.1 and $3 \mathrm{nmol}$ monomer $\mathrm{L}^{-1} \mathrm{~h}^{-1}$ in fall 2008 in aggregatefree and whole seawater, respectively (Fig. 1c).

Chondroitin, arabinogalactan, and fucoidan on average showed lower hydrolysis rates in aggregate-free seawater compared to whole seawater (Fig. 1d-f). Chondroitin sulfate was hydrolyzed at 18.6 and $14.6 \mathrm{nmol}$ monomer $\mathrm{L}^{-1} \mathrm{~h}^{-1}$ in whole seawater and 7.8 and $10.6 \mathrm{nmol}$ monomer $\mathrm{L}^{-1} \mathrm{~h}^{-1}$ in aggregate-free seawater in spring 2006 and fall 2008, respectively (Fig. 1d). For arabinogalacatan and fucoidan, whole seawater rates in spring 2006 were 9.8 and 18.3 nmol monomer $\mathrm{L}^{-1} \mathrm{~h}^{-1}$, respectively; both substrates remained unhydrolyzed in aggregate-free seawaters in spring 2006 (Fig. 1e, f). In fall 2008, arabinogalactan hydrolysis was 5.3 and $4.4 \mathrm{nmol}$ monomer $\mathrm{L}^{-1} \mathrm{~h}^{-1}$ in aggregate-free and whole seawater, respectively. At the same time, fucoidan hydrolysis in whole seawater $\left(8 \mathrm{nmol}\right.$ monomer $\mathrm{L}^{-1} \mathrm{~h}^{-1}$ ) was almost three times higher than in aggregate-free seawater ( $2.7 \mathrm{nmol}$ monomer $\mathrm{L}^{-1} \mathrm{~h}^{-1}$; note that one of the triplicates in aggregate-free seawater showed no hydrolysis, hence the high standard deviation; Fig. 1f).

Total hydrolysis rates in roller bottles were mostly comprised of aggregate-free hydrolytic activity (except for arabinogalactan and fucoidan in spring 2006; Fig. 1). This was due to the relatively low contribution of aggregate volume to the total volume in the roller tanks, as discussed in the previous section.

\subsection{Enzyme activity and half-lives in ASW}

Activities of both commercial enzymes decreased over time, with $\alpha$-glucosidase activity declining more rapidly compared with alkaline phosphatase activity (Fig. 3). Calculated hydrolytic half-lives at $20^{\circ} \mathrm{C}$ ranged between $25 \mathrm{~h}$ for glucosidase and $56 \mathrm{~h}$ for alkaline phosphatase.

\section{Discussion}

The formation of aggregates during roller table incubations notably affected the rates of enzyme activities in seawater. The aggregates were concentrated centers of hydrolytic activities that were typically two to three orders of magnitude higher on a per volume basis than in whole seawater (Table 1). This finding is consistent with previous studies demonstrating that extracellular enzyme activities are enhanced on aggregates (Smith et al., 1992; Ploug et al., 1999;
Grossart et al., 2003, 2007), that can function as hotspots of carbon remineralization (Azam and Long, 2001).

Aggregates themselves occupy a relatively small percentage of a given volume of seawater (estimated here at $0.05 \%$; see Results), however it is important to consider aggregateassociated effects on the surrounding water, since interactions through small-scale fluxes of microorganisms, solutes, and nutrients to and from the surrounding water are substantial (Kiørboe and Jackson, 2001; Kiørboe et al., 2001). Organisms producing extracellular enzymes may preferentially partition onto aggregates, concentrating specific hydrolytic activities in spatially small volumes. Under this scenario, enzyme activity in such aggregates would be equivalent to the sum of activity in a larger volume of water prior to aggregate formation. However, enzyme production by organisms partitioning onto aggregates may also be stimulated by the presence of concentrated substrates, and/or by the presence of other organisms (Grossart et al., 2007). If some of these enzymes are freed into solution - or if organisms not on the aggregates are stimulated to produce enzymes by enhanced production of substrates from the aggregates (Kiørboe and Jackson, 2001; Kiørboe et al., 2001) - net hydrolytic activities in the surrounding seawater, as well as within the aggregates, would be enhanced. As an alternative, activities of specific enzymes may decrease if the organisms producing those enzymes partition onto the aggregates and change the type of enzyme they produce in order to take advantage of substrates on the aggregates. Changes in enzyme production at the genetic level have been observed, for example, for cultures of the marine bacterium Saccharophagus degradans grown on different complex polysaccharides (Weiner et al., 2008). Decreased overall activity for a specific enzyme in a larger volume of seawater could then be due to decreased production of that enzyme on the aggregates and natural decay and/or proteolysis of enzymes originally in the surrounding water.

Our data suggest that increased production of enzymes, concentration of enzymes, and selective modification of the spectrum of enzymes active in seawater occurred in our experiments, pointing towards a highly nuanced enzymatic response among microbial communities. For both laminarin and xylan, rates of enzymatic hydrolysis in the roller bottles (aggregates+aggregate-free seawater) exceeded those of whole seawater at both sampling dates, suggesting that aggregate formation enhanced production of enzymes (Fig. 1a, b). For pullulan on both sampling dates, hydrolysis rates in whole seawater were nearly equal to hydrolysis in roller bottles, suggesting that aggregate formation had relatively little effect on production or activities of these enzymes. For chondroitin, and fucoidan (and for arabinogalactan in spring 2006), activities in the roller bottles were considerably less than in the whole seawater. These decreases in activity are consistent with organisms shifting enzyme production to focus on other substrates, accompanied by decreases in enzyme activity due to enzyme inactivation or degradation. 

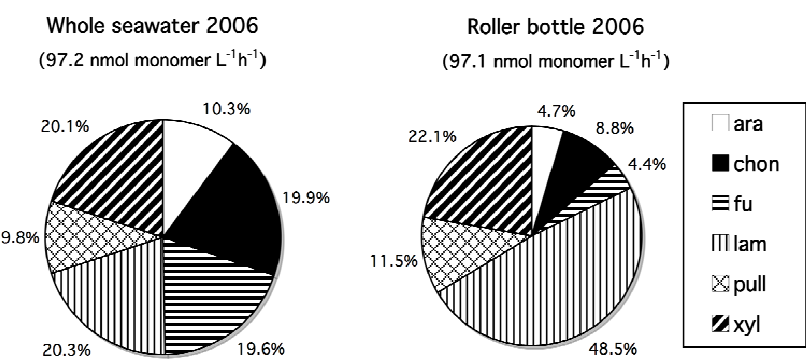

Whole seawater 2008

$\left(77.2 \mathrm{nmol}\right.$ monomer $\left.\mathrm{L}^{-1} \mathrm{~h}^{-1}\right)$
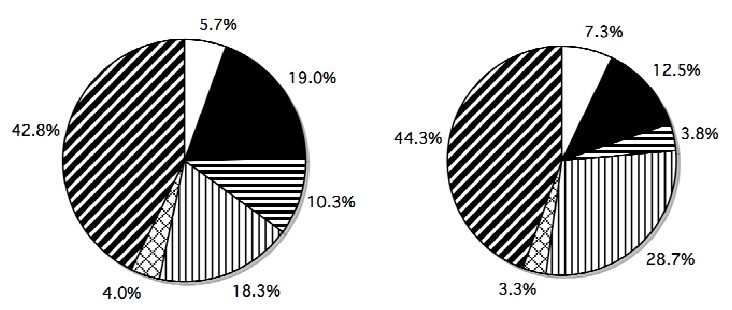

Fig. 2. Relative proportion of laminarin (Lam), xylan (Xyl), pullulan (Pull), chondroitin sulfate (Chon), arabinogalactan (Ara), and fucoidan $(\mathrm{Fu})$ hydrolysis on total hydrolytic activities (sum of all rates per sampling time and experiment given in parenthesis).

The observation of enhanced enzymatic response for xylan and laminarin at both sampling dates suggests specific cellular control of enzyme production. This would be consistent with either control of enzyme expression by quorum sensing (Miller and Bassler, 2001) or enzyme expression in response to the presence of a specific substrate that is concentrated in aggregates (Weiner et al., 2008). At both sampling dates, laminarinase activity in the roller bottles was approximately double that in the whole seawater; for xylanase, the enhancement in enzymatic activity was $10-25 \%$. Laminarin may have been an abundant component of aggregates at both sampling times; it is an energy storage product of diatoms (Painter, 1983), and polysaccharides excreted by diatoms often form the glue for marine snow (Passow, 2002). Xylan is found both among algae and in higher plants (Painter, 1983). High levels of xylanase activity seen in fall 2008 in particular may indicate elevated amounts of terrestrial organic matter in these waters. The more variable activities of arbinogalactan, chondroitin, and fucoidan hydrolases (less enzyme activity in the roller bottles than in whole seawater in spring 2006, similar activity levels in fall 2008) may reflect the extent to which the organisms producing these enzymes changed enzyme production in response to aggregate composition, differences in the quantities and/or activities of enzymes initially present in the seawater, and/or differences in the extent to which those enzymes were hydrolyzed by proteases.

Aggregate formation affected the relative proportion of overall hydrolytic activity attributable to different enzymes, as well as the levels of total activity. Changes in the rela- tive contributions of each enzyme activity to the total were evident for both sampling dates (Fig. 2). For spring 2006, total hydrolytic activities in whole seawater were relatively comparable among all six enzymes, with each contributing 10-20\%. In the roller bottles, however, activities were dominated by laminarinase (48\%), followed by xylanase (22\%), with the other enzyme activities each contributing $4-11 \%$ of the total. Despite this change in the spectrum of enzyme activities, summed activities in whole seawater and in the roller bottle were virtually identical $(97.2$ and $97.1 \mathrm{nmol}$ monomer $\mathrm{L}^{-1} \mathrm{~h}^{-1}$, respectively.) In fall 2008 , however, total activity in whole seawater as well as in the roller bottle was dominated by xylanase $(43 \%$ and $44 \%$, respectively), but changes were seen particularly in the contribution of laminarinase (increased to $29 \%$ in the roller bottles) as well as chondroitin and fucoidin hydrolase (decreased to $13 \%$ and $4 \%$ in the roller bottles, respectively.) Formation of aggregates in fall 2008 was also accompanied by a marked increase in summed activities of all six enzymes, from $77.2 \mathrm{nmol}$ monomer $\mathrm{L}^{-1} \mathrm{~h}^{-1}$ for the whole seawater to $94.0 \mathrm{nmol}$ monomer $\mathrm{L}^{-1} \mathrm{~h}^{-1}$ for the roller bottles. These results demonstrate that the hydrolytic potential of a given volume of seawater is variable, depending in part on the formation/presence of aggregates.

Aggregate formation may stimulate growth and metabolism of both aggregate-associated and free-living microbial communities; the latter are enhanced by high concentrations of dissolved organic matter leaking out of the aggregates as they sink through the water column (Kiørboe and Jackson, 2001; Kiørboe et al., 2001). The aggregates in our experiments may also have stimulated growth and activities of aggregate-free microorganisms by releasing DOC and nutrients into the roller bottles. However, bacterial abundance in aggregate-free seawaters monitored in spring 2006 was five orders of magnitude lower than aggregate-associated microbial abundance (Ziervogel and Arnosti, 2008). We therefore hypothesize that extracellular enzymes that were produced and released by microbes during aggregate formation and that did not partition into aggregates (cell-free enzymes) played a major role in aggregate-free hydrolytic activities.

A number of investigations have demonstrated that the production and release of cell-free enzymes may be a viable feeding strategy for bacteria in particle rich environments such as sediments and aggregates (Vetter et al., 1998). Laboratory experiments show that pure cultures of marine bacteria release enzymes into the surrounding media (Vetter and Deming, 1999; Alderkamp et al., 2007). High levels of dissolved endopeptidase activity in coastal seawater (Obayashi and Suzuki, 2008) also underscore the importance of cell-free enzymes in the ocean. The relative contributions of cell-free enzymes to total hydrolytic activity varies among enzymes; for example, contributions of dissolved laminarinase and xylanase to total hydrolytic activities were found to vary with site and season in a riverine-marine transect (Keith 
and Arnosti, 2001), and varied temporally during the course of a mesocosm bloom (Murray et al., 2007).

The active lifetime of extracellular enzymes in aquatic systems, as well as the extent to which such enzymes are targets of proteases, is largely unexplored. To understand temporal and spatial scales over which cell-free enzymes may retain activity in solution, we carried out an initial experiment to assess the lifetime of two enzymes dissolved in ASW. These results suggest that dissolved enzymes may be active over timescales of hours to several days at $20^{\circ} \mathrm{C}$ (Fig. 3), a temperature relevant to the seawater sampled here. We assume that enzymes produced by microbial communities in seawater are at least as stable intrinsically as are the commerciallyavailable enzymes used here. We hypothesize that the lifetime of enzymes produced by microbial communities in marine environments may have somewhat longer lifetimes than those measured here, since they are likely better 'tuned' to work in extracellular environments than are commercially available enzymes from non-marine sources. Free enzymes released into the water column may rapidly interact with dissolved organic matter or adsorb onto organic or inorganic particles, particularly in particle-rich coastal waters. These processes may help protect them from degradation (Keil et al., 1994) and would likely enhance their hydrolytic lifetimes (Naidja et al., 2000; Huston et al., 2004; Ziervogel et al., 2007). The half-lives of such enzymes relative to natural proteases still needs to be assessed. Experimental evidence, however, suggests that half-lives of dissolved enzymes naturally present in marine waters (albeit at $7{ }^{\circ} \mathrm{C}$; Steen and Arnosti, in revision) are of the same order of magnitude as those measured here at $20^{\circ} \mathrm{C}$. These times are sufficiently long for enzymes to be mixed away from areas of enzyme production and add to hydrolytic activities in the water column.

For Apalachicola Bay, aggregate formation may greatly affect organic matter remineralization processes, as the potential of particle aggregation due to hydrodynamic conditions such as high rates of freshwater discharge as well as wind driven turbulence (Huang et al., 2002; Huang and Spaulding, 2002) is usually high and possibly not limited to seasonal events such as phytoplankton blooms observed in the open ocean. As aggregates tend to accumulate in ripple troughs at the field site (C. Arnosti, unpublished data), aggregate-associated enzyme activities may also affect the sediment elemental cycle whereas enzymes released from sinking aggregates would affect the water column carbon cycle for a more extended period of time. Considering water residence times of up to 10 days in Apalachicola Bay (Huang and Spaulding, 2002), the observed hydrolytic lifetimes of enzymes released from aggregates would be sufficiently long to affect carbon cycling in the Bay as well as in the adjacent Gulf of Mexico.

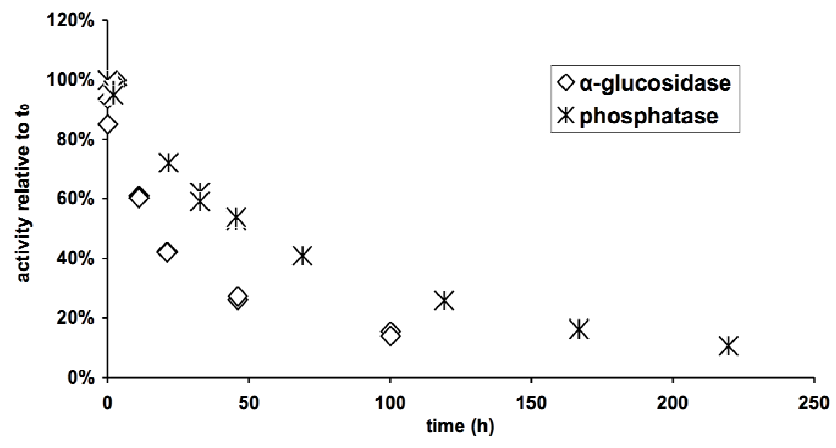

Fig. 3. Changes in enzyme activity over time of commercial enzymes ( $\alpha$-glucosidase and alkaline phosphatase) in ASW.

\section{Conclusions}

Marine snow aggregates constitute densely colonized microbial microenvironments that play an important role in organic matter remineralization in marine environments. Our results show that aggregate formation shapes the nature of microbial enzymatic response to organic matter, changing the spectrum of enzymes produced and affecting the rate and nature of enzymes active in the surrounding water column. Enzyme activities concentrated in the aggregates result in enhanced aggregate-associated hydrolytic activities that affect carbon remineralization on relatively small spatial scales compared to the surrounding water column. In the case of sinking aggregates, aggregate-associated activity can result in the enhanced production of specific cell-free extracellular enzymes that escape from the aggregates, extending hydrolytic activity beyond the spatial 'reach' of the aggregate. These cellfree enzymes that are released from aggregates into the surrounding seawater have the potential to retain activity over timescales sufficiently long to affect carbon remineralization in areas away from their site of production. Aggregate formation can thus lead to spatial as well as temporal decoupling of enzyme activity from microorganisms associated with marine snow. The presence and/or absence of aggregates might therefore in part explain spatial variations in enzyme activities in pelagic ecosystems (Arnosti et al., 2005), and disconnects between enzyme activities and other measures of microbial community activity (Chappell and Goulder, 1995; Murrell and Hollibaugh, 2000).

Acknowledgements. We would like to thank Markus Huettel (FSU) for his hospitality at the FSU Marine Laboratory during the field work. Sherif Ghobrial (UNC) provided invaluable assistance with sampling and processing samples. This work was supported with funding from NSF (OCE-0323975, -0725112, -0848703) and the American Chemical Society's Petroleum Research Fund (40529-AC2) to C.A., a graduate fellowship from E.P.A. to A.D.S., and a postdoctoral fellowship from the Deutsche Forschungsgemeinschaft (ZI 754/2-1) to K.Z.

Edited by: K. Suzuki 


\section{References}

Alderkamp, A. C., van Rijssel, M., and Bolhuis, H.: Characterization of marine bacteria and the activity of their enzyme systems involved in degradation of the algal storage glucan laminarin, FEMS Microbiol. Ecol., 59, 108-117, 2007.

Alldredge, A. L. and Gotschalk, C.: In situ settling behavior of marine snow, Limnol. Oceanogr., 33, 339-351, 1988.

Alldredge, A. L., Cole, J. J., and Caron, D. A.: Production of heterotrophic bacteria inhabiting macroscopic organic aggregates (marine snow) from surface waters, Limnol. Oceanogr., 31, 68$78,1986$.

Arnosti, C.: Measurement of depth- and site-related differences in polysaccharide hydrolysis rates in marine sediments, Geochim. et Cosmochim. Acta, 59, 4247-4257, 1995.

Arnosti, C.: Fluorescent derivatization of polysaccharides and carbohydrate-containing biopolymers for measurement of enzyme activities in complex media, J. Chromatogr. B, 793, 181191, 2003.

Arnosti, C., Durkin, S., and Jeffrey, W. H.: Patterns of extracellular enzyme activities among pelagic marine microbial communities: implications for cycling of dissolved organic carbon, Aquat. Microb. Ecol., 38, 135-145, 2005.

Arnosti, C., Ziervogel, K., Ocampo, L., and Ghobrial, S.: Enzyme activities in the water column and in shallow permeable sediments from the northeastern Gulf of Mexico, Estuar. Coast. Shelf Sci., 84, 202-208, 2009.

Azam, F. and Long, R. A.: Oceanography - Sea snow microcosms, Nature, 414, 495-498, 2001.

Baty, A. M., Eastburn, C. C., Techkarnjanaruk, S., Goodman, A. E., and Geesey, G. G.: Spatial and temporal variations in chitinolytic gene expression and bacterial biomass production during chitin degradation, Appl. Environ. Microbiol., 66, 3574-3585, 2000.

Bidle, K. D. and Fletcher, M.: Comparison of free-living and particle-associated bacterial communities in the Chesapeake Bay by stable low-molecular-weight RNA analysis, Appl. Environ. Microbiol., 61, 944-952, 1995.

Chappell, K. R. and Goulder, R.: A between-river comparison of extracellular-enzyme activity, Microb. Ecol., 29, 1-17, 1995.

Cook, T. L., Sommerfield, C. K., and Wong, K. C.: Observations of tidal and springtime sediment transport in the upper Delaware Estuary, Estuar. Coast Shelf Sci., 72, 235-246, 2007.

DeLong, E. F., Franks, D. G., and Alldredge, A. L.: Phylogenetic diversity of aggregate-attached vs. free-living marine bacterial assemblages, Limnol. Oceanogr., 38, 924-934, 1993.

Gibbs, R. J., Konwar, L., and Terchunian, A.: Size of flocs suspended in Delaware Bay, Can. J. Fish. Aquat. Sci., 40, 102-104, 1983.

Gram, L., Grossart, H. P., Schlingloff, A., and Kiørboe, T.: Possible quorum sensing in marine snow bacteria: Production of acylated homoserine lactones by Roseobacter strains isolated from marine snow, Appl. Environ. Microbiol., 68, 4111-4116, 2002.

Grossart, H. P. and Simon, M.: Significance of limnetic organic aggregates (lake snow) for the sinking flux of particulate organic matter in a large lake, Aquat. Microb. Ecol., 15, 115-125, 1998.

Grossart, H. P., Hietanen, S., and Ploug, H.: Microbial dynamics on diatom aggregates in Oresund, Denmark, Mar. Ecol. Prog. Ser., 249, 69-78, 2003.

Grossart, H. P., Tang, K. W., Kiørboe, T., and Ploug, H.: Comparison of cell-specific activity between free-living and attached bacteria using isolates and natural assemblages, FEMS Microb. Lett., 266, 194-200, 2007.

Hmelo, L. and Van Mooy, B. A. S.: Kinetic constraints on acylated homoserine lactone-based quorum sensing in marine environments, Aquat. Microb. Ecol., 54, 127-133, 2009.

Hoppe, H. G.: Significance of exoenzymatic activities in the ecology of brackish water - Measurements by means of Methylumbelliferyl-substrates, Mar. Ecol. Progr. Ser., 11, 299308, 1983.

Huang, W. R. and Spaulding, M.: Modelling residence-time response to freshwater input in Apalachicola Bay, Florida, USA, Hydrol. Proc., 16, 3051-3064, 2002.

Huang, W. R., Jones, W. K., and Wu, T. S.: Modelling wind effects on subtidal salinity in Apalachicola Bay, Florida, Estuar. Coast. Shelf Sci., 55, 33-46, 2002.

Huston, A. L., Methe, B., and Deming, J. W.: Purification, characterization, and sequencing of an extracellular cold-active aminopeptidase produced by marine psychrophile Colwellia psychrerythraea strain 34 H, Appl. Environ. Microbiol., 70, 33213328, 2004.

Keil, R. G., Montlucon, D. B., Prahl, F. G., and Hedges, J. I.: Sorptive preservation of labile organic matter in marine sediments, Nature, 370, 549-552, 1994.

Keith, S. C. and Arnosti, C.: Extracellular enzyme activity in a river-bay-shelf transect: variations in polysaccharide hydrolysis rates with substrate and size class, Aquat. Microb. Ecol., 24, 243-253, 2001.

Kiørboe, T. and Jackson, G. A.: Marine snow, organic solute plumes, and optimal chemosensory behavior of bacteria, Limnol. Oceanogr., 46, 1309-1318, 2001.

Kiørboe, T., Ploug, H., and Thygesen, U. H.: Fluid motion and solute distribution around sinking aggregates. I. Small-scale fluxes and heterogeneity of nutrients in the pelagic environment, Mar. Ecol. Progr. Ser., 211, 1-13, 2001.

Kiørboe, T., Tang, K., Grossart, H. P., and Ploug, H.: Dynamics of microbial communities on marine snow aggregates: Colonization, growth, detachment, and grazing mortality of attached bacteria, Appl. Environ. Microbiol., 69, 3036-3047, 2003.

Martinez, J. and Azam, F.: Periplasmic aminopeptidase and alkaline-phosphatase activities in a marine bacterium - Implications for substrate processing in the sea, Mar. Ecol. Progr. Ser., 92, 89-97, 1993.

Miller, M. B. and Bassler, B. L.: Quorum sensing in bacteria, Ann. Rev. Microb., 55, 165-199, 2001.

Mortazavi, B., Iverson, R. L., and Huang, W. R.: Dissolved organic nitrogen and nitrate in Apalachicola Bay, Florida: spatial distributions and monthly budgets, Mar. Ecol. Progr. Ser., 214, 79-91, 2001.

Mortazavi, B., Iverson, R. L., Landing, W. M., Lewis, F. G., and Huang, W. R.: Control of phytoplankton production and biomass in a river-dominated estuary: Apalachicola Bay, Florida, USA, Mar. Ecol. Progr. Ser., 198, 19-31, 2000.

Murray, A. E., Arnosti, C., De La Rocha, C. L., Grossart, H. P., and Passow, U.: Microbial dynamics in autotrophic and heterotrophic seawater mesocosms. II. Bacterioplankton community structure and hydrolytic enzyme activities, Aquat. Microb. Ecol., 49, 123141, 2007.

Murrell, M. C. and Hollibaugh, J. T.: Distribution and composition of dissolved and particulate organic carbon in northern San 
Francisco Bay during low flow conditions, Estua. Coast. Shelf Sci., 51, 75-90, 2000.

Naidja, A., Huang, P. M., and Bollag, J. M.: Enzyme-clay interactions and their impact on transformations of natural and anthropogenic organic compounds in soil, J. Environ. Qual., 29, 677-691, 2000.

Obayashi, Y. and Suzuki, S.: Occurrence of exo - and endopeptidases in dissolved and particulate fractions of coastal seawater, Aquat. Microb. Ecol., 50, 231-237, 2008.

Painter, T. J.: Algal polysaccharides, in: The polysaccharides, edited by: Aspinall, G. O., Academic Press, New York, 195-285, 1983.

Passow, U.: Transparent exopolymer particles (TEP) in aquatic environments, Progr. Oceanogr., 55, 287-333, 2002.

Ploug, H., Grossart, H. P., Azam, F., and Jorgensen, B. B.: Photosynthesis, respiration, and carbon turnover in sinking marine snow from surface waters of Southern California Bight: implications for the carbon cycle in the ocean, Mar. Ecol. Progr. Ser., 179, 1-11, 1999.

Riemann, L. and Grossart, H. P.: Elevated lytic phage production as a consequence of particle colonization by a marine Flavobacterium (Cellulophaga sp.), Microb. Ecol., 56, 505-512, 2008.

Shanks, A. L. and Edmondson, E. W.: Laboratory-made artificial marine snow: a biological model of the real thing, Mar. Biol., 101, 463-470, 1989.

Simon, M., Grossart, H. P., Schweitzer, B., and Ploug, H.: Microbial ecology of organic aggregates in aquatic ecosystems, Aquat. Microb. Ecol., 28, 175-211, 2002.

Smith, D. C., Simon, M., Alldredge, A. L., and Azam, F.: Intense hydrolytic enzyme activity on marine aggregates and implications for rapid particle dissolution, Nature, 359, 139-142, 1992.

Steen, A. D. and Arnosti, C.: Slow decay of extracellular phosphatase, $\beta$-glucosidase, and leucine aminopeptidase in Arctic seawater, Limnol. Oceanogr., in revision, 2010.

Tuomainen, J., Hietanen, S., Kuparinen, J., Martikainen, P. J., and Servomaa, K.: Community structure of the bacteria associated with Nodularia sp. (cyanobacteria) aggregates in the Baltic Sea, Microb. Ecol., 52, 513-522, 2006.
Unanue, M. A., Azua, I., Arrieta, J. M., Herndl, G. J., and Iriberri, J.: Laboratory-made particles as a useful approach to analyse microbial processes in marine macroaggregates, FEMS Microb. Ecol., 26, 325-334, 1998.

Vetter, Y. A. and Deming, T. W.: Growth rates of marine bacterial isolates on particulate organic substrates solubilized by freely released extracellular enzymes, Microb. Ecol., 37, 86-94, 1999.

Vetter, Y. A., Deming, J. W., Jumars, P. A., and Kreiger-Brockett, B. B.: A predictive model of bacterial foraging by means of freely released extracellular enzymes, Microb. Ecol., 36, 75-92, 1998.

Weiner, R. M., Taylor, L. E., Henrissat, B., Hauser, L., Land, M., Coutinho, P. M., Rancurel, C., Saunders, E. H., Longmire, A. G., Zhang, H. T., Bayer, E. A., Gilbert, H. J., Larimer, F., Zhulin, I. B., Ekborg, N. A., Lamed, R., Richardson, P. M., Borovok, I., and Hutcheson, S.: Complete genome sequence of the complex carbohydrate-degrading marine bacterium, Saccharophagus degradans strain 2-40(T). PLOS Genet., 4, e1000087. doi:10.1371/journal.pgen.1000087, 2008.

Weiss, M. S., Abele, U., Weckesser, J., Welte, W., Schiltz, E., and Schulz, G. E.: Molecular architecture and electrostatic properties of a bacterial porin, Science, 254, 1627-1630, 1991.

Wolanski, E. and Gibbs, R. J.: Flocculation of suspended sediment in the Fly River Estuary, Papua-New-Guinea, J. Coast. Res., 11, 754-762, 1995.

Ziervogel, K. and Arnosti, C.: Polysaccharide hydrolysis in aggregates and free enzyme activity in aggregate-free seawater from the north-eastern Gulf of Mexico, Environ. Microbiol., 10, 289299, 2008.

Ziervogel, K. and Arnosti, C.: Enzyme activities in the Delaware Estuary affected by elevated suspended sediment load, Estua. Coast. Shelf Sci., 84, 253-258, 2009.

Ziervogel, K., Karlsson, E., and Arnosti, C.: Surface associations of enzymes and of organic matter: Consequences for hydrolytic activity and organic matter remineralization in marine systems, Mar. Chem., 104, 241-252, 2007. 